\title{
Political ideologies as shapers of future tourism development
}

\author{
Craig Webster and Stanislav Ivanov
}

Craig Webster is an Assistant

Professor at the Department of Family and Consumer

Sciences, Ball State University, Muncie, Indiana, USA.

Stanislav Ivanov is based at the Varna University of Management, Varna, Bulgaria.
Received 13 May 2015 Revised 10 July 2015 Accepted 16 July 2015 (c) Craig Webster and Stanislav Ivanov. Published in the Journal of Tourism Futures.

This article is published under the Creative Commons Attribution (CC BY 4.0) licence. Anyone may reproduce, distribute, translate and create derivative works of this article (for both commercial and non-commercial purposes), subject to full attribution to the original publication and authors. The full terms of this licence may be seen at: http:// creativecommons.org/ licences/by/4.0/legalcode

\begin{abstract}
Purpose - The purpose of this paper is to identify the link between political ideology and the management of tourism in countries. The authors stipulate that the predominant political ideology in the country influences the nature and logic of state interventions in the tourism industry.

Design/methodology/approach - The paper elaborates several case studies from various countries Bulgaria, Cyprus, Scandinavia, Russia, USA, China, Japan, Indonesia, and North Korea.

Findings - Countries with predominant (neo)liberal ideology do not typically interfere in tourism regulation, while nationalism leads governments to stimulate inbound and domestic tourism. Communist ideological approaches tend to be burdensome, inhibiting growth while stressing the promotion of the socialist achievements of a country. Countries that are traditionally thought of as social democratic have been evolving in recent years to regulate tourism in ways that are more liberal in nature than social democratic.

Practical implications - Political ideologies shape the acceptability of government support for private tourist companies, legislation in field of tourism, limitation/stimulation of inbound/outbound tourist flows. For the future the authors expect greater politicisation of tourism, active tourism "wars" between countries, greater control of governments on populations, thriving nationalism, "aggressive" environmentalism.

Originality/value - This is one of the first papers to discuss the impact of the political ideology on the management of tourism at the national level.
\end{abstract}

Keywords Politics, Tourism policy, Macro environment, Political ideologies

Paper type Viewpoint

\section{Introduction}

This paper analyses the impact of political ideas and systems of thinking on tourism in the future. The main premise of the work is that political and economic institutions are created first in the minds of people and that the institutions are a reflection of values and assumptions regarding the nature of humans and the nature of political and economic reality. There is a continuing interest in academic circles in the role of ideas on political outcomes and institutions (see, e.g. Campbell, 1998, 2002; Lowndes and Roberts, 2013), although this is rarely looked into in the field of tourism, with some exceptions (such as, Britton, 1982, 1991; Hall, 2004; Jeffries, 2001; Desforges, 2000; Stevenson et al., 2008). Therefore, we seek to look into how the mindsets of people lead to specific sets of economic and political organisation for tourism currently and look at trends to determine whether the trajectory is sustainable or it appears that certain events/developments may derail the trajectory.

The key concept that needs to be defined for this investigation is the idea of "ideology". There is a continuing controversy regarding the definition and meaning of "ideology" (Sargent, 1996, p. 3), so this sort of investigation becomes especially difficult, as it is premised upon a concept that is by its very nature controversial. There are other related concepts as "theory" and "philosophy" that will be used in this work as well that also defy a global/universal agreement regarding their definition. At any rate, there is a voluminous literature dealing with political 
thought, whether labelled as "philosophy", "theory", or "ideology" (see, e.g. Freeden, 2003; Heywood, 2012, 2015; Kymlicka, 2001; Schwarzmantel, 2008; Vincent, 2009; Wolff, 2006; Zizek, 1989). However, for our purposes, we use "ideology" and "philosophy" as pertaining to systems of thought that are generally internally consistent and pertain to an understanding of the interrelationships between state, market, and society.

To begin with, this work will not look particularly at ideologies of political economy, as this has been done elsewhere (e.g. Webster and Ivanov, 2012; Webster et al., 2011). Although the theoretical perspectives on political economy are related to the theoretical perspectives on politics, the thinking systems are also separate and can be understood separately. As political ideologies deal with the central concepts of how to organise a society to make them consistent with human nature and human needs, political economy ideologies deal with a somewhat more narrow focus, on how to organise an economy. Although the two are related, they can be considered and will be considered here in a broader way than merely looking into the prescriptive approach of various frameworks of political economy.

In addition, the intent of this piece is not to look into how tourism changed countries, bring foreign ideas into countries and causing social and political change. While tourism may bring people into foreign locations, enabling the spread of new ideas, whether the new ideas are quite directly political and forcing political change or more social in nature, changing the way that people live their lives, this is not the central point of this piece. Instead, the intention of this paper is to look at ways in which the prevailing systems of thought of elites and the institutions that have been forged by such prevailing systems of thought have played a role in terms of state approaches towards tourism.

In this piece, we first delineate the various political ideologies that exist and are available to political leaders. To do this, we delve into how political theorists delineate and isolate the various political ideologies that currently exist. Here, we investigate the major political ideologies and look at how they view the role of tourism. We then explore how ideologies of politics have been incorporated into the politics of tourism in various countries, with case studies from a number of countries. We then assess how these ideologies will likely impact upon tourism throughout the world. Finally, we conclude making projections of how political thinking will impact upon tourism in the future and noting how future research can look into the impact of ideology on tourism in the future.

\section{The ideologies of politics and tourism}

To begin the investigation, we have to examine the various ideologies that currently exist and characterize how various theorists delineate political ideologies. To begin with, we look into how a few influential works have identified types of ideologies. Table I illustrates the language and categorisations with which several leading authors on political theory have isolated specific ways of thinking.

Table I Major political ideologies

\begin{tabular}{|c|c|c|c|c|}
\hline Ideology & Schumaker et al. (1997) & $\begin{array}{l}\text { Terminology } \\
\text { Sargent (1996) }\end{array}$ & Macridis (1986) & Vincent (2009) \\
\hline Conservatism & $\begin{array}{l}\text { Traditional conservatism } \\
\text { Contemporary conservatism }\end{array}$ & Contemporary conservatism & Conservatism & Conservatism \\
\hline Liberalism & $\begin{array}{l}\text { Classical liberalism } \\
\text { Contemporary liberalism }\end{array}$ & Contemporary liberalism & Democratic liberalism & Liberalism \\
\hline Anarchism & Anarchism & Anarchism & Anarchism & Anarchism \\
\hline Marxism & $\begin{array}{l}\text { Marxism } \\
\text { Communism } \\
\text { Democratic socialism }\end{array}$ & $\begin{array}{l}\text { Marxism } \\
\text { Democratic socialism } \\
\text { Democratic capitalism }\end{array}$ & $\begin{array}{l}\text { Communism } \\
\text { Democratic socialism } \\
\text { Utopian socialism }\end{array}$ & Socialism \\
\hline $\begin{array}{l}\text { Fascism/national socialism } \\
\text { Environmentalism }\end{array}$ & $\begin{array}{l}\text { Fascism and nazism } \\
\text { Environmentalism }\end{array}$ & $\begin{array}{l}\text { Fascism and national socialism } \\
\text { Environmentalism }\end{array}$ & Fascism/nazism & $\begin{array}{l}\text { Fascism } \\
\text { Ecologism }\end{array}$ \\
\hline Other ideologies referred to & $\begin{array}{l}\text { Feminism } \\
\text { Fundamentalism }\end{array}$ & $\begin{array}{l}\text { Nationalism } \\
\text { Feminism } \\
\text { Third World ideologies } \\
\text { Liberation theology } \\
\text { Islam }\end{array}$ & Nationalism & $\begin{array}{l}\text { Nationalism } \\
\text { Fundamentalism } \\
\text { Feminism }\end{array}$ \\
\hline
\end{tabular}


What is most noteworthy is that there are notable overlaps in terms of the language and concepts between the various authors. For example, while all the authors have mentioned conservatism as an ideology, those who are not particularly in the field of the study of political theory would likely find it hard to imagine that conservatism is a system of thought and could be thought of as an ideology. What is also noteworthy is the recurrence of anarchism as a concept, while the language of the ideology seems to be remarkable stable between these authors.

A further interesting issue is the delineation of environmentalism as an ideology. While many of us who do not study political theory as a profession would be rather surprised to think of environmentalism (or "ecologism") as a political ideology, it seems that those who do think of political theory as a profession do think of it as a separate system of thinking from other ideologies. Surely, some aspects of environmentalism/ecologism have filtered into all sorts of political parties that are affiliated with other ideologies; however, we see that those who deal with political theory think of it as a separate category.

With this overview of the ideologies and the conceptualisation of different closed systems of thought, we see that there is not only considerable overlap and similarity in language but there is also a great deal of diversity in the other ideologies referred to. While there is considerable attention given to the five leading ideologies, even while the language is very similar from author to author, the "other" category shows a great deal of diversity. What is also noteworthy is that the category "Marxism" for all the authors is treated as non-monolithic, obviously making it a difficult thing to deal with, as Marxism encompasses all sorts of varieties. What is especially interesting is that Vincent (2009) treats "Marxism" and "socialism" as virtual synonyms, something that many other authors would disagree with.

The "other" category, a catchall term for those ideologies that seem not to fit neatly into the prevailing categories is especially interesting as it is where the interesting ideologies of the future may be found. While it has been noted that the prevailing ideologies in the world are all Western in origin (Huntington, 2011), these authors suggest a foreshadowing of the rise of ideologies that are non-Western in nature. Indeed, such movements as Ba'athism and Kemalism are arguably political theories, if not self-contained ideologies, neither of which has a particularly Western genesis.

While the major political philosophies seem to show that there are a multitude of various ways of thinking about how to organise a society, two leading books in Comparative Politics (O'Neil, 2012; Draper and Ramsay, 2012) isolate fewer of them. O'Neil (2012) distils the major ideologies into communism, social democracy, liberalism, fascism, and anarchism. Draper and Ramsay (2012) deal only with social democracy, "extreme market democracy", Christian democracy, and communism. While noting the multitude of ideologies and variations of ideologies that exist, it is necessary to limit the discussion to the prevailing ideologies that have stood the test of time, for the purpose of this investigation.

One brief comment that should be made is that ideologies seem to reflect a particular purpose, as Macridis (1986, p. 13) notes. They are either status quo, revolutionary, or reformist systems of thinking about reality. These labels mean that the ideologies imply that there is either something worthwhile in the status quo and seeks to reinforce and preserve the status quo or seeks either radical changes or gradual changes to make a better order. What is intriguing about this notion is that it implies that ideologies are not neutral but are partisan players, seeking either to preserve or change the current economic, political, and social order.

In terms of assessing the major current ideologies and what they say about tourism, many things can be said, as Table II illustrates. To begin, because the role of the state in liberal and anarchist ideologies remains minimal in scope, there is very little room for the state. Thus for these ideologies, the role of the state is minimal based upon the perception of the desirability or importance of the state. While liberals view the state as a necessary evil, anarchists simply view it as an evil that acts as an impediment to human freedom. From this very basic standpoint on the state, the state cannot really be an attractive vehicle to supply or support tourism. However, the nature and logic of how tourism is appreciated in both these systems of thought, is a bit different, as liberalism views leisure and tourism as things that are consumed and purchased through a market mechanism by individuals. Anarchists, on the other hand would stress the communal aspects of tourism and leisure. The differences between liberal and anarchist thinking are critical 
Table II Major political ideologies and tourism

\begin{tabular}{|c|c|c|c|c|}
\hline Ideology & Role of the state & $\begin{array}{l}\text { Role of the } \\
\text { individual }\end{array}$ & $\begin{array}{l}\text { Priority of tourism in the } \\
\text { society }\end{array}$ & $\begin{array}{l}\text { How it should be enjoyed/ } \\
\text { supplied }\end{array}$ \\
\hline Liberalism & Limited & $\begin{array}{l}\text { Purchased and } \\
\text { enjoyed by the } \\
\text { individual }\end{array}$ & $\begin{array}{l}\text { Low, except for economic } \\
\text { development purposes }\end{array}$ & Market-supplied \\
\hline Anarchism & None & $\begin{array}{l}\text { Enjoyed } \\
\text { communally }\end{array}$ & $\begin{array}{l}\text { High, as it is linked with the } \\
\text { high value of freedom }\end{array}$ & Society-supplied \\
\hline Communism & $\begin{array}{l}\text { Provision of tourism and leisure of time } \\
\text { during dictatorship of the proletariat, no } \\
\text { role after socialist phase is past }\end{array}$ & $\begin{array}{l}\text { Enjoyed } \\
\text { communally }\end{array}$ & $\begin{array}{l}\text { High, as it is linked with } \\
\text { entitlements of the working } \\
\text { class }\end{array}$ & $\begin{array}{l}\text { State-supplied, society-supplied } \\
\text { (in later historical stages) }\end{array}$ \\
\hline $\begin{array}{l}\text { Social } \\
\text { democracy }\end{array}$ & $\begin{array}{l}\text { Provision of legal framework to ensure } \\
\text { leisure and tourism opportunities, state } \\
\text { regulation to ensure leisure and tourism }\end{array}$ & $\begin{array}{l}\text { Purchased and } \\
\text { enjoyed by the } \\
\text { individual }\end{array}$ & $\begin{array}{l}\text { High, as it is linked with } \\
\text { entitlements of the working } \\
\text { class }\end{array}$ & $\begin{array}{l}\text { Mostly market-supplied but such } \\
\text { supply ensured by substantial } \\
\text { state interventions into the market }\end{array}$ \\
\hline $\begin{array}{l}\text { Fascism/ } \\
\text { National } \\
\text { Socialism }\end{array}$ & $\begin{array}{l}\text { Provision of legal framework to ensure } \\
\text { leisure and tourism opportunities, state/ } \\
\text { party intervention to ensure leisure and } \\
\text { tourism }\end{array}$ & $\begin{array}{l}\text { Provided by the } \\
\text { state and market } \\
\text { and enjoyed } \\
\text { communally }\end{array}$ & $\begin{array}{l}\text { High, as it is linked with a } \\
\text { system of rewards for the } \\
\text { loyalty of the working } \\
\text { classes }\end{array}$ & $\begin{array}{l}\text { Mixture of state and market forces } \\
\text { supplying tourism opportunities }\end{array}$ \\
\hline
\end{tabular}

in terms of understanding the role of tourism in a society. From a liberal perspective, tourism is not particularly important in a society, apart from the role that it may play in the economy. In addition, a liberal perspective would stress the market in its ability to provide tourism opportunities. Opposed to this is an anarchist's viewpoint that tourism is important, as it would be reflective of social values of leisure and social interaction, although it would be understood that much of this would be supplied by a society, rather than a market.

The other ideologies all have a more state-based approach towards tourism. While the communist approach envisions a post-socialist future that will be very similar to the utopia envisioned by anarchists, the pathway to that utopia for communists consists of stages in which the state plays a critical role in the supply of many things in the society. Communist, socialdemocratic, and fascist approaches all envision the state as being deeply involved in tourism for various different reasons. From a communist approach, tourism is envisioned as an entitlement of the working class, something that implies that the state should work in ways to ensure that there is adequate provision of this for all, but especially the working class. Much of the same would be expressed by social democratic thinking, as they are from the same Marxist roots. However, social democratic thinking enables the market to also be involved in the provision of leisure and tourism opportunities for all. What is intriguing is that the fascist approach uses much of the same mixture of market and state forces to provide tourism. This is no coincidence, as fascist thinking is always in a competitive situation with socialist thinking to achieve the loyalty of the working class.

In total, what we see is that there are very different ways at looking at tourism from the perspective of different ideologies. What we particularly notice is that the role of the state in the regulation and provision of tourism varies a great deal by the political ideology adhered to. We see that state provision and regulation of tourism is particularly acute in fascist and communist mindsets, while there is some involvement in this in social democratic approaches. What is also noteworthy is that liberal and social democratic approaches put significant stress upon the importance of market forces.

In terms of the current global paradigm of politics, we see that liberalism or neo-liberalism has been in a position of dominance in recent decades. Liberal institutions such as the WTO, IMF, and World Bank have generally championed liberal models of economic development. What is interesting is that this continual expansion globally upon the insistence on the market playing a key role in society has been increasingly widespread. However, ideologies of populations and segments of populations within countries have had a slightly different influence upon the practice and provision of tourism in many countries. Now, we turn to case studies to look at how these ideologies have either conformed to the liberal global consensus or resisted the global consensus regarding liberalism and make projections about the trajectory of liberal ideas regarding the practice and provision of tourism and alternative visions that come from opposed ideologies. 


\section{Case studies: ideological influences on tourism and tourism management}

In this section we discuss the influence of political ideologies on tourism in several countries.

\section{Bulgaria}

Until 1989 Bulgaria was part of the Soviet bloc. The strong grip of communist ideology put its mark onto tourism and tourism management. First of all, all tourist companies were government owned - private tourism activity was allowed for private accommodations (rooms) only. This ownership structure allowed the tourist companies to be managed in a coordinated way, which led to their high bargaining power during negotiations with foreign tour operators. The tourism sector was managed by the governmental Tourism Committee (Ivanov and Dimitrova, 2014) with strong management functions over the tourism industry of the country. Furthermore, communist ideology led to the development of social tourism and organised leisure for the masses. On one hand, tourism was perceived as a tool to proclaim the achievements of the communist regime among domestic and foreign tourists. On the other hand, the affordability of annual 10-14-day domestic holiday trips, for example, created among Bulgarian population the perception of good standard of living and diverted much of the thoughts questioning the political system.

After 1989 the predominant political ideologies of the ruling party changed. After the havoc of the early 1990s, the mass privatisation fiasco during the same period and the hyperinflation in the winter of 1996-1997 resulting in mass civil protests, in 1997 a government with mixed conservative and neoliberal ideas took power. Tourism industry was privatised to a degree that as of today (March 2015) it is completely private. This practice was carried on by the neoliberal government of the former king at the beginning of the twenty-first century. The result was the emergence of multitude of small tourist companies with low bargaining power and virtually no tools to influence the large foreign charter tour operators. However, tourism industry experienced explosive growth, created many jobs (Ivanov, 2005), and offset partially the loss of jobs in other sectors of the economy (mostly the industry and the agriculture). The final outcome of the neoliberal philosophy was the closure of the State Agency for Tourism in 2009. For several years the country did not have a separate government institution to deal with the management of tourism industry. The agency's functions were transferred to the Ministry of Economy, Energy and Tourism. In 2014 a new four-partite coalition government was formed, following the election results leading a highly partitioned parliament. The outcome was that the new government unites parties with diverse and often opposing political ideologies - conservatism, socialism, nationalism, neo-liberalism/social democracy. In some decisions of the government it is evident that the arguments of one of the ideologies prevail, while in other decisions it relies on the arguments of other ideologies. Nevertheless, the positive consequence for tourism is that for the first time in Bulgarian history a separate Ministry of Tourism was created in November 2014.

\section{Russia}

During the last 15 years the current Russian president applied the nationalist ideology and the "inclusive" strategy - the ruling party, for example, is named "United Russia". Following the sanctions, resulting from the Autonomous Republic of Crimea's transition from Ukraine to the Russian Federation, in the light of the nationalist ideology the government started to actively stimulate domestic tourism and adopted outbound tourism substitution strategy. Tourist flows are directed to Sochi and Crimean peninsula, instead of Balkan and Mediterranean countries via active advertising and dedicated TV series on the virtues of domestic tourist resources of the federation. Tourism is perceived as the instrument to stimulate Crimea's economy which suffered heavily from the sanctions and the loss of the Ukrainian market. The Simferopol airport is being expanded (Koteneva, 2015) and the former military airport of Belbek in Sevastopol starts receiving civil flights from summer 2015 (Vzglyad, 2014). These actions increase the accessibility of the peninsula from other regions of Russia, thus making it more attractive for domestic tourists.

\section{North Korea}

North Korea is a classic example of the impact of communist ideology on its tourism industry. The country offers organised and strictly controlled visits of foreign tourists. Tourist groups are 
assigned a dedicated guide and travel on predetermined routes. Tourism is, therefore, highly politically overburdened and is perceived as a way to trumpet the achievements of the communist system (ideologically) and source of foreign exchange (pragmatically). However, prior research reveals that tourism may serve as a tool for peace building on the Korean peninsula (Webster and Ivanov, 2014). What is noteworthy is that in the North Korean case, a very special Stalinist version of communist thinking with a very nationalist bent to it has rejected liberal models completely, and has only in the smallest ways accepted the benefits of markets and market interactions since the Korean War (Kim et al., 2007). Such a rejection of the possible benefits of markets has retained North Korea's tourism industry as a state-controlled industry with only very small scale forays into tourism and even when tourism is explored by the state, it is under very strict governmental controls.

\section{USA}

The liberal philosophy in the USA and the specific federal organisation of the country result in the lack of a national destination management organisation (DMO) but the existence of many DMOs on city/county/state levels. The Office of Travel and Tourism Industries within the Department of Commerce, is largely a "think tank" dealing with research, data collection and policy recommendations (Webster et al., 2011). The twin features of a federal structure paired with a strong philosophical preference for market-based solutions work in ways to ensure that the US Federal Government plays a very minor role in the tourism industry. While there has been an indication that the Federal Government would become more involved in the marketing of the USA's tourism product following the 9/11 attacks in 2001, the promised money to fund such a marketing campaign never materialized. Two things seem to stick out from the USA's experience. First, it seems that since the eighteenth century Constitution of the USA did not specifically mention tourism, states have retained the power to deal with tourism-related issues. However, it seems that when a true threat to possible tourism flows to the USA were in the horizon, the Federal Government was willing to take action. The liberal philosophy towards the regulation of tourism and the federal system of government have ensured a very laissez-faire approach towards tourism in the USA, although it seems that when the very success of the USA as a destination was threatened, the political leadership was willing to act in ways that seem pragmatic to bolster tourism, rather than based upon a stubborn allegiance to ideological principles and deferring to states' rights.

\section{Cyprus}

Tourism plays a major role in this divided island, as there is a general lack of natural resources while the geography and location of the island make it a logical sun, sand, and sea mecca for tourists. At its inception in 1960, the Republic of Cyprus was a poor country that faced a major ethnic division. The country descended into civil war in the 1960s that eventually petered out. Then in 1974, an Athens-backed coup led to a short-term ousting of the president. This, in turn, led to a partial invasion by Turkey, leading to a division of the island with about one-third in the hands of the government of "the Turkish Republic of Northern Cyprus" and the remainder under the government of the internationally recognised Republic of Cyprus.

The division of the island and the administration of tourism in both sections is a very political issue (Altinay and Bowen, 2006), due to the centrality of tourism in the economy. In both political entities on the island, tourism has been a key element in the economy, and the government has worked in ways to ensure that tourism is promoted and sometimes invisible to consumers (Andronicou, 1986; Farmaki et al., 2015). For example, cheaper round-trip air tickets in the summer of 2015 on Turkish Airlines from Istanbul to Northern Nicosia cost around USD100 for the hour-and-a-half direct flight, a cost that is suspiciously low, unless substantial tax advantages and subsidies are given to airlines to operate at such a low cost.

In terms of the politics of tourism regulation in both political entities on the island, the government plays a central role. While the "Turkish Republic of Northern Cyprus" is a pariah state of sorts, as it lacks international recognition, its governmental authorities have embraced Turkey as a source market for tourists, largely promoting what Turkey does not have, casinos. Although there are few data sources that would be considered reliable for this micro-economy, the political entity's reliance on subsidies and tourism from Turkey must be substantial. 
The World Travel and Tourism Council (2014) estimate that travel and tourism contributes to 24 per cent of GDP in the Republic of Cyprus, making tourism a major part of the economy and the political authorities recognise this. In the Republic of Cyprus, the semi-governmental Cyprus Tourism Organisation is under the responsibility of the Ministry of Commerce, Industry and Tourism, with substantial regulatory powers.

What is interesting about the tourism industry in both entities is the centrality of politics in the tourism industry. While in the "Turkish Republic of Northern Cyprus" the political reality of isolation of the political entity has led to the government exploiting linkages with Mainland Turkey (Yasarata et al., 2010; Alipour and Kilic, 2005; Altinay, 2000), the Republic of Cyprus' authorities have followed strategies that are largely based upon mass tourism, in an attempt to capture as much volume as possible. In both political entities, the state has retained a key role in the promotion and regulation of tourism, clearly defying liberal principals but also clearly not for redistributive purposes, but is done more in line with nationalist ideology.

\section{Scandinavia}

What is interesting is that Scandinavia (here referring to Iceland, Norway, Sweden, Finland, and Denmark) has had a very strong and sustained influence of social democratic parties following the Second World War. The concept of social democracy was adopted by Scandinavian societies following the Second World War, leading to societies with very developed welfare state policies as while there was a noteworthy market economy functioning in each of the Scandinavian countries. The concept of social democratic governance led to very strong governmental interventions into the economy, leading to very high income tax levels in all the Scandinavian states, with the intention to redistribute the wealth to the poorer strata of society. This concept was referred to as folkhemmet (meaning "people's home") in Sweden, suggesting that the state should act in ways making the country a comfortable home for the working people. The concept of redistributing wealth to the poorer classes via all sorts of welfare including universal healthcare, free university education, and a myriad of other welfare benefits has made the Scandinavian countries some of the most equal countries in the world, according to most measures of inequalities within countries, although there is indication that there is a shift towards more inequality (OECD, 2011). The social democratic ideal has largely been achieved throughout Scandinavia, where taxes remain staggeringly high and welfare benefits generous.

However, in terms of tourism, the states in Scandinavia have not been afraid of being involved in the regulation of and promotion of tourism. In all the countries, the government was fairly generous in funding NTOs and supporting all sorts of efforts to promote national tourism products. This was done largely via outright ownership of NTOs that would promote tourism abroad, gather data on tourism flows, and sponsor all sorts of activities to support and promote tourism. The governments following the Second World War also held large shares of ownership in airlines either alone (Icelandair, Finnair) or working together in partnerships with other governments (Scandinavian Air Systems). This meant that the governments played a role in owning a major transportation network that would deliver tourists to/from Scandinavia.

However, in recent years, there has been a gradual introduction of ideas that are more oriented with market needs, rather than social and political goals (Webster et al., 2011). What this has meant in practice is that Scandinavian countries have moved towards having the state less involved in the promotion and marketing of tourism products, moving much of the responsibilities to firms that are privately owned. The most radical example of this is in Finland, where the former government owned and controlled National Tourism Office was reduced in size greatly, with most of the promotion and marketing responsibilities being shifted to a private firm. In Norway in 2004, the government consolidated several organisations into Innovation Norway, one of which was the Norwegian Tourist Board. The Norwegian consolidation of tourism into another larger organisation was also followed by much more recent (2014) proposals by the government to privatise the Airport Express train. The general movement towards marketoriented solutions is a general movement in Scandinavia, suggestive that some of the more statist responses to the regulation of tourism are being abandoned. This movement away from statist involvement in the economy seems to be moving in tandem with a waning political hegemony that social democratic parties have in many Scandinavian countries. 
The Liberal Democratic party of Japan has controlled the government of Japan almost continuously since the Second World War, with the exception of five years. Despite the name of the leading party in Japan, the party has been very stubborn in terms of controlling and managing the economy in Japan and tourism is no exception (Webster et al., 2011). While most successive governments in Japan since the Second World War have been "liberal" in name, attitudes towards the economy and attitudes towards regulating the economy veer far from the liberal ideal, with the state and industry working in conjunction to plan and control the economy and tourism is no exception to this. The Japanese National Tourism Organization, formed in 1964, is an administrative arm of the government of Japan that deals with many aspects regarding the promotion of tourism in Japan and abroad.

One of the key elements in the regulation of tourism for Japan is the key role that the government plays in the control of the inflow of tourists (Soshiroda, 2005), in the marketing to tourists (Uzama, 2009), and in the tourism industry in Japan (Zhang and McCornac, 2014). While the Japanese Government has been in control of a political party that is liberal in name, the presence of the state is omnipresent in the tourism industry, although the intention of policy is not a social democratic ideal (redistributing wealth) but seems to be more in line with a nationalist ideology, intending to create a stronger industry to be in line with building a stronger national economy.

\section{China}

China is a rather enigmatic country, as the Communist Party of China retains a monopoly on political power in the country while it has simultaneously relinquished a great deal of control over the economy. The prevailing current philosophy of the Communist Party developed out of the ideological struggles within the party in 1960s and 1970s. The ideological problematic was that the Communist Party came to political power in a country that had largely avoided the development of a capitalist class. The ideological argument was that the government needed to foster capitalist development under socialist control in order for a true socialist/communist order to develop. As a result, China has been largely enigmatic in that it has embraced capitalism while under strict control of the Communist Party.

In terms of tourism, enigmatically, the government has retained a great deal of control over the tourism industry, even when the government has largely embraced the free market for many other economic activities. The China National Tourism Administration is a governmental authority that has considerable authority in terms of the regulation of tourism in China as well as performs research and marketing for the Chinese tourism product abroad (Bao et al., 2014; Su and Teo, 2009; Weaver, 2015). Wang and Shu (2012) claim that Chinese tourism associations are more political and less marketing-oriented since they are government owned and are not operated independently in terms of marketing or management of the association members. The authors state that there is no independent association due to the fact that no association in China can form an association without government approval and involvement. What is interesting about China is that while the government for several decades has embraced the free market, tourism has remained largely exempt from this and has retained a high level of governmental involvement and regulation, although it seems that the current government is also targeting foreign investors in recent years (Wall Street Journal, 2014), as the current leadership seems to be reflecting a certain amount of economic nationalism.

\section{Indonesia}

When Indonesia became independent following the Second World War and following the war with the Netherlands in its attempt to re-establish its control over Indonesia, the government of President Sukarno was rather typical of those countries that became independent following the Second World War. The government followed an authoritarian model while contending with a powerful Communist Party and military that threatened intervention in the political system. In terms of the economic policies of the government, the government operated largely upon mercantilist logic, with the government retaining a great deal of control and ownership of the industries and natural resources of the country. However, that changed drastically in 1968 when President Suharto became installed as the Head of the Government. 
President Suharto, who served as the President until 1998, oversaw a massive transition in the economy, moving towards liberalisation of the economy. He also played a key role in large-scale arrests and massacres of members of the Communist Party and suspected members of the party. In this strong movement towards liberalisation/capitalism, the state privatised many of its industries and raw materials and largely embraced the capitalist powers in the last decades of the Cold War. What is enigmatic is that Indonesia has an economy that is highly liberalised, although the Ministry of Tourism remains a fully state-owned enterprise (Cole, 2008). So, it seems that while the government since the late 1960s moved away from governmental control of the economy, tourism has remained a Cabinet-level ministry, showing the importance that tourism is perceived to have (Sofield, 1995).

\section{Future developments in political ideologies and their impact on tourism}

\section{Politicisation of tourism}

The economic and social importance of tourism has long made it a tool for achieving political goals. Furthermore, the existence of many stakeholders in tourism with countering interests has made it a highly politicised area of public debate. For example, being non-local residents, tourists are a lucrative target for taxation - it is politically convenient to levy taxes on non-voting non-residents (e.g. via hotel room tax, entrance fees to museums and attractions) than on voting local residents. Local authorities in New York, Jamaica, Dubai, Bulgaria, among others, use room taxes/tourist taxes to fund projects and generate revenues in local budgets. However, tourist senvices are often subject to lower VAT tax and tax refunds in order to make the destination price competitive and attract more tourists (e.g. in Bulgaria the VAT on tourist services is 9 per cent while the normal rate is 20 per cent). Furthermore, tourism is sometimes perceived by politicians as an instrument to generate votes and win elections through satisfying the interests of some of the stakeholders - for instance, subsidising the infrastructure construction, renovation or expansion (conservative/social democratic approach), vouchers to local residents to be used for domestic tourism (socialist approach), tax breaks for investors in municipalities with high unemployment rate (conservative/liberal approach), removal or simplification of regulations towards tourism businesses (liberal approach), etc. Political ideologies differ on the basis of: who would be supported - the tourist companies (conservatism, social democracy, liberalism) or the tourists (socialism); and how would the support be provided - indirect support: elimination of tax and regulatory burden on tourist companies (liberalism), provision of public assets and services needed to tourists and tourist companies (conservatism, social democracy) or direct support: vouchers for use of tourist services, subsidies for tourist companies (socialism).

Additionally, tourism is used for promotion of political ideologies (e.g. communist heritage tourism in North Korea and China) and stimulating nationalism and sense of national identity (domestic tourism, visits to museums and important historical places by children) which makes it politically burdened. In the Russian Federation it has even been considered as the tool for quick economic and social integration of Crimean peninsula after its cessation from Ukraine in March 2014. Furthermore, extremist and fundamentalist groups might perceive foreign tourists as carriers of unwanted social and cultural influence which could make them targets for terrorist attacks. And foreign tourists are lucrative targets for terrorist attacks because of the high visibility of such attacks due to their extensive media coverage and the "popularity" extremists gain.

For the future we expect further politicisation of tourism. As tourism grows and reaches more geographic areas and involves more social strata, either as tourists and/or as employees/owners of tourism enterprises, it expands its social reach which increases the number of tourism stakeholders and the diversity of interests which public authorities need to face. However, we think that governments would not adopt a one-size-fits-all ideology in dealing with tourism but they will use different mechanisms from the arsenals of different ideologies depending on the situation and their political convenience. This means that sometimes one government would provide tax breaks to big investors in tourism in order to decrease the unemployment, other times it would invest heavily in infrastructure, while in third cases it may provide incentives to local residents to undertake domestic trips. Such situational pragmatic ideological approach by public authorities seems more probable as it is satisfies the interest of many stakeholders although not necessarily the interests of society as whole. 


\section{Tourism wars}

A natural consequence of the politicisation of tourism is the tourism wars. They relate to the aggressive destination marketing and in general can be applied by both destinations and tourist generating countries. When applied by destinations tourism wars refer to the diverting ("stealing") of inbound tourists from competitor destinations. When applied by tourist generating countries tourism wars include redirecting outbound tourist flows from one destination to another) as a substitute and extension of political "wars". As discussed above, the transition of the Autonomous Republic of Crimea in March 2014 and the subsequent international economic and political sanction on the Russian Federation resulted in stimulation of domestic tourism and recommendations by the Russian officials to citizens not to travel to countries that support the sanctions (BurgasNews, 2015). As Russian tourists contribute significantly to the economies of Greece, Cyprus, Turkey, Bulgaria, Egypt and other countries, the governments and tourism enterprises in these countries worried about the expected plummeting numbers of tourist arrivals from Russia. The reactions included: subsidising charter flights from Russia to Turkey (socialdemocratic approach) (Vestnik Kavkaza, 2015), simplified visa issue process for Russian tourists visiting Greece (liberal approach) (Greek Travel Pages, 2015), or even voices from Bulgarian tourism industry for compensation from the EU for missed revenues (socialist approach) (News.bg, 2015). For the future we expect such tourist wars to continue and sometimes even worsen. They would be used by major tourist generating countries as a powerful economic tool to redirect tourist and financial flows from one (inconvenient) destination to another. Destinations that depend heavily on tourism to create employment for its citizens and for foreign exchange earnings would be highly vulnerable.

\section{Environmentalism}

Environmentalism has permeated the agenda of political parties, governments and NGOs. It is no longer just "save the planet" way of thinking emphasising economic use of resources, use of renewable energy, waste separation, recycling and so on. Environmentalism has now received the qualities of a political doctrine per se - it is organised (e.g. Greenpeace and other organisations), influences our daily life (e.g. compulsory home waste separation), regulates the economic activities (e.g. ISO 14000: environmental management; EU requirements about renewable energy's share in total energy production within the union) and its issues are discussed on top political and global level (e.g. UN's Agenda 21). Tourism is largely perceived as one of the major contributors to global warming/climate change (Simpson et al., 2008). Therefore, tourism's interactions with global warming/climate change and the sustainable tourism development have been widely discussed both by practitioners and the academia (e.g. Borges et al., 2014; Lopez-Sanchez and Pulido-Fernandez, 2014; Scott et al., 2012; Weaver, 2006) and have been included in the goals and activities of various tourism organisations. For the future we expect much greater role of sustainability thinking in governments and local authorities, leading to the infusion of even more "aggressive" green thinking in tourism organisations - e.g. compulsory offsetting of the carbon footprint for every tourist, compulsory minimum percentage of renewable energy in the total energy consumption of tourism enterprises, expansion of protected areas and limited access to them, severe regulations on water consumption and transportation in resorts, etc. The outcome would be increased costs of tourist services, and probably, decreased affordability of tourist trips, but in exchange of better quality of the environment. In general, tourism would benefit from the greater role of environmentalism in the political system. However, environmentalism should not be hindrance to the economic development of local communities and the latter should not be put into the position to choose jobs or environment. In the future, we think, the potential choice "jobs or environment" (e.g. the ecologists stopping the development of resorts and infrastructure) would be transformed into "jobs and environment" (tourist go to places with proper environment management).

\section{Greater control on populations}

The political goal of achieving greater control on populations might lead to the use of tourism as a tool to introduce and spread faster the human radio-frequency identification (RFID) microchip implants (Ivanov et al., 2013). Through tourism, neo-conservative governments might popularise 
the benefits of implanted RFID microchips - smooth and fast passage at airports and frontier control points, electronic visa, no need of carrying physical ID/passport/cash/credit or debit cards, greater security of travel, no need of foreign exchange, etc. Therefore, tourism would be the instrument through which governments to achieve higher goals - i.e. greater control on populations' movement, purchases, daily lives. We have already observed RFID human microchip implants used to access offices and use various appliances (Reuters, 2015) and believe this tendency would continue in the future in larger scale.

\section{Thriving nationalism}

New nations find nationalism and domestic tourism as tools for nation-building. The heritisation, antiquisation and the glorification of the past become vital steps in the process. The governments construct monuments, dedicated to the victorious ancient rulers and prominent figures from nation's history, sometimes regardless of the historical facts, use tourism to promote the real and invented national heritage. The new city centre of Skopje, the capital of the Republic of Macedonia, is a good example - the nationalist ideology and the aim of the political elite of the country (creating a new nation and giving it past it could be proud of led to the erection of monuments disputed by Greece (e.g. Alexander the Great) and Bulgaria (e.g. King Samuil). Domestic tourism to these new places of national worship strengthens the sense of national identity of residents. We envision this heritisation process to continue in the foreseeable future due to the growth of heritage tourism demand in general and its sub-segments (e.g. communist heritage tourism - Ivanov, 2009) and the cessation processes in many countries leading to new nations that need "new pasts" (Webster and Ivanov, 2015).

\section{Conclusion}

There are many things to be said with regards to how ideologies will play a role in the future. One of the major issues that will have to be contended with is the necessary friction between nationalism and liberalism. While liberalism is by definition an internationalist movement, especially in its current neo-liberal embodiment, it faces all sorts of public and governmental resistance. The resistance is largely based upon the way in which populations cling to nation-states as a form of organisation, giving populations a sense of security. One of the ideological clashes that will remain for some time in the future is the clash between international liberalism and nationalist/ conservative resistance movements.

Many states seem to already have retained control or partial control over tourism and have not allowed tourism to be at the mercy of the free market. We see in the Asian countries surveyed that even when the countries have shown a dedication to liberalism, the state has retained tourism as something of political/strategic value and is thus largely under political regulation. This is especially interesting, as it illustrates that while liberalism and markets may be the stated mantra, the states in these cases, have maintained political organisations to deal with the industry. In the future, it seems that states will be more involved with the regulation of tourism, perhaps as a backlash to the neo-liberalism of recent decades.

What is also interesting is the slow and partial retreat from social democracy in Scandinavia. While the states there have begun to increasingly embrace market-based principles, substantial government involvement in the economy and regulation of tourism still takes place. However, the reorganisation and partial retreat from strong governmental control, ownership, and regulation of tourism seems to go hand-in-hand with the general decline in the power of social democratic parties in Scandinavia. Although much of the value system of social democracy is deeply engrained in Scandinavian populations, partial privatisations of tourism-related industries and the reorganisation of political institutions dealing with tourism are possible, although they do meet with some resistance. So, it seems that the slow decline of social democratic institutions relating to tourism in Scandinavia mirrors the general decline of social democratic parties in there, as well.

What is most interesting in this investigation is the question of liberalism and all the other ideologies that oppose it. With the global ascendance of liberalism, we see that there is resistance at all levels. The most interesting and most successful seems to be nationalism that rears its head and limits liberal forces. However, other non-liberal ideologies also have opportunities to counter 
liberal tourism, although nationalism and conservatism seem to be ideologies that have the best chances in terms of launching successful opposition, as they largely are able to work in conjunction with state forces to oppose liberalisation. It is noteworthy that there are a number of states mentioned above that have stated their support for liberal policies and yet they retain strong institutions that have the potential for regulating tourism or do regulate tourism.

In terms of future research, it would be good to survey political elites to look at how they envision the role of tourism in their countries and ask they what role that they feel that tourism could play in their country in future decades. This would be interesting and useful work as it would entail asking leaders about their faith and reliance upon international tourism markets rather than the nation-level regulation of tourism. Surveys could also be conducted to determine whether these elites feel that tourism should be regulated, as the negative externalities may entail cultural or political threats. Mapping out how political elites look at tourism and how it may threaten the political and cultural independence in countries would seem to be fruitful, especially if it entails delinking economic liberalisation with westernisation.

Another key concern that should be considered is to look at how political ideologies impact upon security concerns and economic concerns. While in the present epoch, tourism is typically thought of as an economic vehicle to assist countries in increasing living standards and does not have an ideological component, the ideological preferences of elites and state institutions also play a role. Much a similar case could be made in discussing security concerns. Future research should look more specifically into how ideological preferences of elites are mitigated by economic pragmatism and concerns regarding the security of the state. Although few states would compromise a great deal of their security or economic development for the ideological preferences of elites, some significant sacrifices may be made. For example, the German hotelier, Fritz Gabler, in National Socialist Germany stated that tourism and autarky were conceptually incompatible (Semmens, 2011). Gabler's comment was a mild criticism of National Socialist policies in 1934, suggesting that the principles of autarky of the National Socialists were not helpful for the tourism industry in Germany. However, the ideology guiding the National Socialists did not place tourism development as a high priority for the regime. There are probably other similar examples from more recent history, when regimes either for security reasons or ideological reasons were willing to give up the use of tourism as a pathway to economic development. Certainly, the case of North Korea is an instance in which, for the most part, the elites have been willing to give up economic development via tourism either for security reasons or some other ideological reasons that are still rather vague. What future works should look into is the interaction of ideology, security, and economic development.

Another key concern in work on ideology is the perception of ideology. What may seem pragmatic and acceptable to a liberal may be ideological to an anarchist, for example. So while economic development may seem to be an ideologically neutral goal for a state and while security concerns for states may also seem to be ideologically neutral, they really are. Indeed, pragmatism is in the eye of the beholder.

In closing, this research has looked into how ideology is set to play a role in future tourism. While it may seem that liberalism is the wave of the future and that most governments have embraced liberal principles, it appears that many governments have not actually done this, even if they have pretended to do so. There is substantial evidence that governments have either retained institutions that have the ability to be given greater powers, in the event from a withdrawal from liberal policies (as in the case of Indonesia) or have retained powerful institutions that have retained high levels of control of tourism, despite stated liberal policies (as in the case of Japan).

What is noteworthy is that it seems that ideology seems to have some flexibility, in recognition of the value that tourism has for the economy. Thus, while the ultra-liberal USA professes a hands-off approach towards tourism, when its massive tourism industry was thought to be at risk, there was substantial support for governmental stimulus. On the other hand, Stalinist North Korea has shown a steady rejection of market principles, although the ideology of Juche was relaxed a bit in order to permit limited tourism development in the country. So while ideology may shape organisational responses to dealing with tourism, there still seems to be considerable room for manoeuvre within each ideology based upon pragmatism. So it seems that the very interesting thing to look at in the future is when governments fully reject ideological principles upon which 
their tourism industries rest, based upon practical solutions that work and defy ideological prejudices. But even these practical/pragmatic solutions will meet with resistance within societies and political institutions if they clash with important cultural values linked with nationalism, conservatism, and (in Scandinavia) social democracy.

\section{References}

Alipour, H. and Kilic, H. (2005), "An institutional appraisal of tourism development and planning: the case of the Turkish Republic of North Cyprus (TRNC)", Tourism Management, Vol. 26 No. 1, pp. 79-94.

Altinay, L. (2000), "Possible impacts of a federal solution to the Cyprus problem on the tourism industry of North Cyprus", International Journal of Hospitality Management, Vol. 19 No. 3, pp. 295-309.

Altinay, L. and Bowen, D. (2006), "Politics and tourism interface: the case of Cyprus", Annals of Tourism Research, Vol. 33 No. 4, pp. 939-56.

Andronicou, A. (1986), "Cyprus - management of the tourist sector", Tourism Management, Vol. 7 No. 2 , pp. 127-9.

Bao, J., Chen, G. and Ma, L. (2014), "Tourism research in China: insights from insiders", Annals of Tourism Research, Vol. 45, pp. 167-81.

Borges, M., Eusébio, C. and Carvalho, N. (2014), "Governance for sustainable tourism: a review and directions for future research", European Journal of Tourism Research, Vol. 7, pp. 45-56.

Britton, S.G. (1982), "The political economy of tourism in the third world", Annals of Tourism Research, Vol. 9 No. 3, pp. 331-58.

Britton, S.G. (1991), "Tourism, capital and place: towards a critical geography of tourism”, Environment and Planning, Vol. 9 No. 4, pp. 451-78.

BurgasNews (2015), "Russia forbids its military servicemen to spend their holidays in Bulgaria", BurgasNews, 23 March, available at: www.burgasnews.com/novini-burgas/84878-rusiya-zabranila-na-voennite-si-dapochivat-u-nas (accessed 29 March 2015).

Campbell, J.L. (1998), "Institutional analysis and the role of ideas in political economy", Theory and Society, Vol. 27 No. 3, pp. 377-409.

Campbell, J.L. (2002), "Ideas, politics, and public policy", Annual Review of Sociology, Vol. 28, pp. 21-38.

Cole, S. (2008), Tourism, Culture and Development: Hopes, Dreams and Realities in East Indonesia, Channel View Publications, Clevedon.

Desforges, L. (2000), "State tourism institutions and neo-liberal development: a case study of Peru", Tourism Geographies, Vol. 2 No. 2, pp. 177-92.

Draper, A. and Ramsay, A. (2012), The Good Society: An Introduction to Comparative Politics, 2nd ed., Pearson, Harlow.

Farmaki, A., Altinay, L., Botterill, D. and Hilke, S. (2015), "Politics and sustainable tourism: the case of Cyprus", Tourism Management, Vol. 47, pp. 178-90.

Freeden, M. (2003), Ideology: A Very Short Introduction, Oxford University Press, Oxford.

Greek Travel Pages (2015), "MITT 2015: Russian travellers are loyal to greece, no visa problem from greek side", available at: http://news.gtp.gr/2015/03/20/mitt-2015-russian-travellers-are-loyal-to-greece-no-visaproblem-from-greek-side/ (accessed 28 March 2015).

Hall, C.M. (2004), "The role of government in the management of tourism: the public sector and tourism policies", in Pender, L. and Sharpley, R. (Eds), The Management of Tourism, Sage Publications, Thousand Oaks, CA, pp. 217-30.

Heywood, A. (2012), Political Ideologies: An Introduction, 5th ed., Palgrave Macmillan, Basingstoke.

Heywood, A. (2015), Political Theory: An Introduction, 4th ed., Palgrave Macmillan, London.

Huntington, S. (2011), The Clash of Civilizations and the Remaking of World Order, Simon and Schuster, New York, NY.

Ivanov, S. (2005), "Effectiveness of tourism in generating jobs and incomes in Bulgaria", in Neshkov, M., et al. (Eds), Bulgarian Tourism - Management and Effectiveness, Slavena, Varna, pp. 94-111. 
Ivanov, S. (2009), "Opportunities for developing communist heritage tourism in Bulgaria”, Tourism, Vol. 57 No. 2, pp. 177-92.

Ivanov, S. and Dimitrova, M. (2014), 'Managing tourism in Bulgaria: between 'mission impossible' and new hope”, in Costa, C., Panyik, E. and Buhalis, D. (Eds), European Tourism Planning and Organisation Systems, Vol. II, National Case Studies, Channel View Publications, Clevedon, pp. 87-105.

Ivanov, S., Webster, C. and Mladenovic, A. (2013), "The microchipped tourist: implications for European tourism”, in Postma, A., Oskam, J. and Yeoman, I. (Eds), The Future of European Tourism, Stenden University of Applied Sciences, Leeuwarden, pp. 86-106.

Jeffries, D. (2001), Governments and Tourism, Butterworth-Heinemann, Oxford.

Kim, S.S., Timothy, D.J. and Han, H.C. (2007), "Tourism and political ideologies: a case of tourism in North Korea”, Tourism Management, Vol. 28 No. 4, pp. 1031-43.

Koteneva, O. (2015), "Reconstruction of Simferopol airport would continue till 1st June", available at: www.rg. ru/2015/03/04/reg-kfo/airport.html (accessed 27 March 2015).

Kymlicka, W. (2001), Contemporary Political Philosophy: An Introduction, 2nd ed., Oxford University Press, Oxford.

López-Sánchez, Y. and Pulido-Fernández, J.I. (2014), "Incorporating sustainability into tourism policy: a strategic agenda for Spain", European Journal of Tourism Research, Vol. 7, pp. 57-78.

Lowndes, V. and Roberts, M. (2013), Why Institutions Matter: The New Institutionalism in Political Science, Palgrave MacMillan, London.

Macridis, R.C. (1986), Contemporary Political ldeologies: Movements and Regimes, 3rd ed., Little, Brown and Company.

News.bg (2015), "Hoteliers want compensations from EU for the decreased number of Russian tourists", available at: http://news.ibox.bg/news/id_4824913 (accessed 28 March 2015).

OECD (2011), "An overview of growing income inequalities in OECD countries: main findings", OECD, Paris, available at: www.oecd.org/els/soc/49499779.pdf (accessed 12 May 2015).

O'Neil, P. (2012), Essentials of Comparative Politics, 4th ed., W.W. Norton and Company, New York, NY.

Reuters (2015), "Microchips implanted under the skin of office workers", YouTube video, Reuters, available at: www.youtube.com/watch?v=NBTK8cFajYE (accessed 28 March 2015).

Sargent, L.T. (1996), Contemporary Political Ideologies: A Comparative Analysis, Wadsworth, Belmont, CA.

Schumaker, P., Keil, D.C. and Heilke, T.W. (1997), Ideological Voices: An Anthology in Modern Political Ideas, McGraw-Hill, New York, NY.

Schwarzmantel, J.J. (2008), Ideology and Politics, Sage, London.

Scott, D., Hall, C.M. and Gössling, S. (2012), Tourism and Climate Change: Impacts, Adaptation and Mitigation, Routledge, Oxon.

Semmens, K. (2011), “'Tourism and autarky are conceptually incompatible': international tourism conferences in the Third Reich", in Zuelow, E.G.E. (Ed.), Tourism Beyond the Nation: A Transnational Approach to European Tourism History, Ashgate, Surrey, pp. 195-213.

Simpson, M.C., Gössling, S., Scott, D., Hall, C.M. and Gladin, E. (2008), Climate Change Adaptation and Mitigation in the Tourism Sector: Frameworks, Tools and Practices, UNEP, University of Oxford, UNWTO, WMO, Paris.

Sofield, T.H.B. (1995), "Indonesia's national tourism development plan”, Annals of Tourism Research, Vol. 22 No. 3, pp. 690-4.

Soshiroda, A. (2005), "Inbound tourism policies in Japan from 1859 to 2003", Annals of Tourism Research, Vol. 32 No. 4, pp. 1100-20.

Stevenson, N., Airey, D. and Miller, G. (2008), "Tourism policy making”, Annals of Tourism Research, Vol. 35 No. 3, pp. 732-50.

Su, X. and Teo, P. (2009), The Politics of Heritage Tourism in China: A View from Lijiang, Routledge, Oxon.

Uzama, A. (2009), "Marketing Japan's travel and tourism industry to international tourists", International Journal of Contemporary Hospitality Management, Vol. 21 No. 3, pp. 356-65. 
Vestnik Kavkaza (2015), "Turkey will protect Russian tourists from the crisis", available at: http:// vestnikkavkaza.net/news/tourism/65834.html (accessed 28 March 2015).

Vincent, A. (2009), Modern Political Ideologies, 3rd ed., Wiley Blackwell, Chichester.

Vzglyad (2014), "In 2015 Belbek airport would start receiving regular flights", Vzglyad, 4 December, available at: www.rg.ru/2014/12/04/reg-kfo/belbek-anons.html (accessed 27 March 2015).

Wall Street Journal (2014), "Beijing vs Foreign Capitalist Roaders. China uses antitrust as a tool of economic nationalism", Wall Street Journal, 14 August, available at: www.wsj.com/articles/beijing-vs-foreign-capitalistroaders-1408034745 (accessed 12 May 2015).

Wang, S. and Shu, R. (2012), "Call for fully functional and distinct CVBs in China: a case of Hangzhou", Tourism Today, Vol. 12, pp. 52-64.

Weaver, D. (2006), Sustainable Tourism, Butterworth-Heinemann, Oxford.

Weaver, D. (2015), "Tourism and the Chinese dream: framework for engagement", Annals of Tourism Research, Vol. 51, pp. 54-6.

Webster, C. and Ivanov, S. (2012), "The political economy of tourism in the future", in Leigh, J., Webster, C. and Ivanov, S. (Eds), Future Tourism: Political, Social and Economic Challenges, Routledge, Oxon, pp. 21-34.

Webster, C. and Ivanov, S. (2014), "Tourism as a force for political stability", in Wohlmuther, C. and Wintersteiner, W. (Eds), The International Handbook on Tourism and Peace, Drava Verlag, Klagenfurt, pp. 167-80.

Webster, C. and Ivanov, S. (2015), "Geopolitical drivers of future tourist flows", Journal of Tourism Futures, Vol. 1 No. 1, pp. 58-68.

Webster, C., Ivanov, S. and Illum, S. (2011), "The paradigms of political economy and tourism policy: NTOs and state policy", in Mosedale, J. (Ed.), Political Economy and Tourism, Routledge, Oxon, pp. 55-73.

Wolff, J. (2006), An Introduction to Political Philosophy, Oxford University Press, Oxford.

World Travel and Tourism Council (2014), Travel and Tourism Economic Impact 2014: Cyprus, WTTC, London.

Yasarata, M., Altinay, L., Burns, P. and Okumus, F. (2010), "Politics and sustainable tourism development can they co-exist? Voices from North Cyprus", Tourism Management, Vol. 31 No. 3, pp. 345-56.

Zhang, R. and McCornac, D.C. (2014), "Challenges for the international tourism industry in Japan - an agent for economic recovery and development”, Almatourism, Vol. 5 No. 10, pp. 109-24.

Zizek, S. (1989), The Sublime Object of Ideology, Verso, New York, NY.

\section{Further reading}

Baggio, R., Scott, N. and Cooper, C. (2010), "Improving tourism destination governance: a complexity science approach", Tourism Review, Vol. 65 No. 4, pp. 51-60.

Cohen-Hattab, K. (2004), "Zionism, tourism, and the battle for Palestine: tourism as a political-propaganda tool", Israel Studies, Vol. 9 No. 1, pp. 61-85.

Cothran, C.C. and Cothran, D.A. (1998), "Promise or political risk for Mexican tourism”, Annals of Tourism Research, Vol. 25 No. 2, pp. 477-97.

Hall, C.M. (1994), Tourism and Politics: Policy, Power and Place, John Wiley and Sons, Chichester.

Hall, C.M. (2011), "A typology of governance and its implications for tourism policy analysis", Journal of Sustainable Tourism, Vol. 19 No. 4, pp. 437-57.

Hall, C.M., Teo, P. and Chang, T.C. (2001), "Tourism and political relationships in South-East Asia", in Teo, P., Chang, T.C. and Ho, K.C. (Eds), Interconnected Worlds: Tourism in Southeast Asia, Elsevier, Oxford, pp. 13-26.

Horejsova, T. and Paris, C.M. (2013), "Tourism and the challenge of arctic governance", International Journal of Tourism Policy, Vol. 5 No. 1, pp. 113-27.

Krutwaysho, O. and Bramwell, B. (2010), "Tourism policy implementation and society", Annals of Tourism Research, Vol. 37 No. 3, pp. 670-91.

Noel, A. and Therien, J.P. (2008), Left and Right in Global Politics, Cambridge University Press, Cambridge. 
Nunkoo, R. (2014), "Correlates of political trust and support for tourism", in Nunkoo, R. and Smith, S.L.J. (Eds), Trust, Tourism Development and Planning, Routledge, Oxon, pp. 143-67.

Nunkoo, R. and Smith, S.L. (2013), "Political economy of tourism: trust in government actors, political support, and their determinants", Tourism Management, Vol. 36, pp. 120-32.

Opaschowski, H.W. (1998), "The future of leisure, culture and tourism. The challenge for politics and society", World Leisure and Recreation, Vol. 40 No. 2, pp. 8-14.

Sharpley, R. (2009), "Dark tourism and political ideology: towards a governance model", in Sharpley, R. and Stone, P.S. (Eds), The Darker Side of Travel: The Theory and Practice of Dark Tourism, Channel View Publications, Bristol, pp. 145-63.

van den Berghe, P.L. and Flores Ochoa, J. (2000), "Tourism and nativistic ideology in Cuzco, Peru", Annals of Tourism Research, Vol. 27 No. 1, pp. 7-26.

Wolter, H. (2006), "Tourism under the Nazis", The Journal of Transport History, Vol. 27 No. 2, pp. 143-73.

Yeoman, I. (2009), Tomorrow's Tourist: Scenarios and Trends, Routledge, Oxon.

Yeoman, I. (2012), 2050-Tomorrow's Tourism, Channel View Publications, Clevedon.

\section{Corresponding author}

Stanislav Ivanov can be contacted at: stanislav.ivanov@vumk.eu

For instructions on how to order reprints of this article, please visit our website: 